
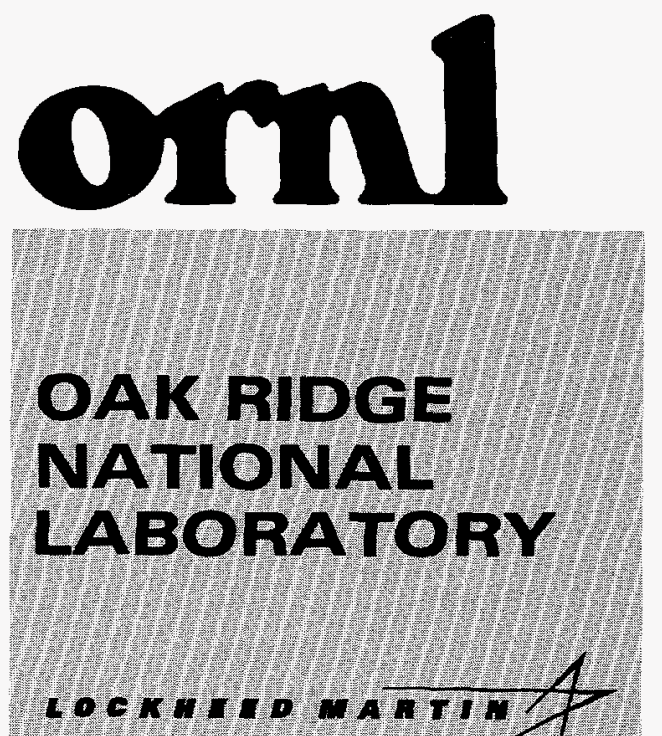

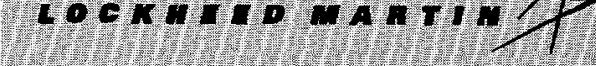

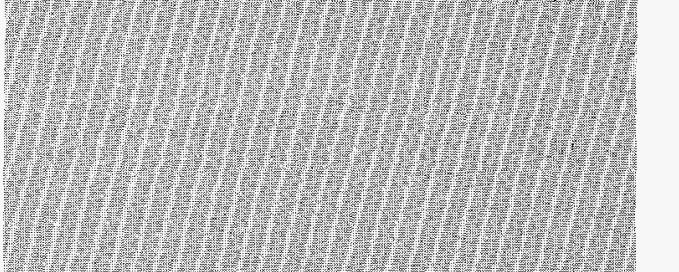

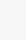

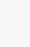

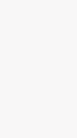

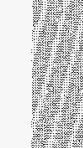

\section{Jui 2 \\ 0 s}

$$
\begin{array}{r}
\text { ORNL/M }-5935 \\
\text { C/ORNL93-0243 }
\end{array}
$$

\author{
CRADA Final Report \\ for \\ CRADA Number ORNL93-0243
}

GELCASTING OF ALUMINUM TITANATE

S. D. Nunn

Oak Ridge National Laboratory

J. E. Stephan

Golden Technologies Company, Inc.

\author{
Prepared by the \\ Oak Ridge National Laboratory \\ Oak Ridge, Tennessee 37831 \\ managed by
Lockheed Martin Energy Research Corporation \\ for the \\ U.S. Department of Energy \\ under contract DE-AC05-96OR22464
}

APPROVED FOR PUBLIC RELEASE

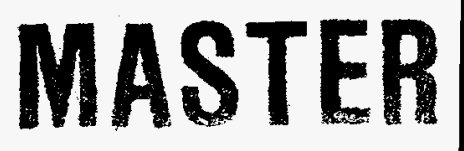

\section{UNLIMITED DISTRIBUTION}


This report has been reproduced directly from the best available copy.

Available to DOE and DOE contractors from the Office of Scientific and Technical Information, P. O. Box 62, Oak Ridge, TN 37831 ; prices available from (423) 576-8401, FTS 626-8401.

Available to the public from the National Technical Information Service, U.S. Department of Commerce, 5285 Port Royal Road, Springfield, VA 22161.

This report was prepared as an account of work sponsored by an agency of the United States Government. Neither the United States Government nor any agency thereof, nor any of their employees, makes any warranty, express or implied, or assumes any legal liability or responsibility for the accuracy, completeness, or usefulness of any information, apparatus, product, or process disclosed, or represents that its use would not infringe privately owned rights. Reference herein to any specific commercial product, process, or service by trade name, trademark, manufacturer, or otherwise, does not necessarily constitute or imply its endorsement, recommendation, or favoring by the United States Government or any agency thereof. The views and opinions of authors expressed herein do not necessarily state or reflect those of the United States Government of any agency thereof. 


\section{DISCLAMMER}

Portions of this document may be illegible in electronic image products. Images are produced from the best available original document. 
CRADA Final Report

for

CRADA Number ORNL93-0243

\title{
GELCASTING OF ALUMINUM TITANATE
}

S. D. Nunn

Oak Ridge National Laboratory

J. E. Stephan

Golden Technologies Company, Inc.

\author{
Prepared by the \\ Oak Ridge National laboratory \\ Oak Ridge, Tennessee 37831 \\ managed by \\ Lockheed Martin Energy Research Corporation \\ for the \\ U.S. Department of Energy \\ under contract DE-AC05-96OR22464
}

Unlimited Distribution 


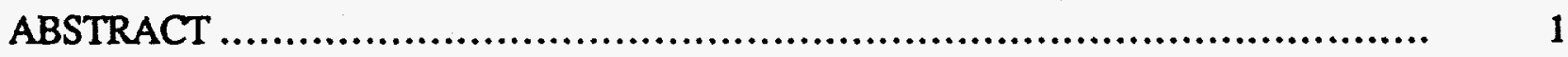

CRADA OBJECTIVES................................................................ 1

MEETING OBJECTIVES ....................................................... 1

CRADA BENEFIT TO DOE........................................................ 1

TECHNICAL DISCUSSION .................................................. 1

REPORT OF INVENTIONS .................................................... 3

COMMERCIALIZATION POSSIBILITIES ....................................... 3

PLANS FOR FUTURE COLLABORATION ....................................... 3

CONCLUSIONS................................................................... 3

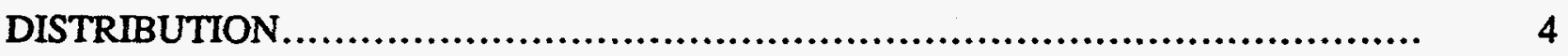

Research sponsored by the U.S. Department of Energy, Assistant Secretary for Energy Efficiency and Renewable Energy, Office of Transportation Technologies, as part of the Heavy Vehicle Propulsion System Materials Program, under contract DE-AC05960R22464 with Lockheed Martin Energy Research Corporation. 


\begin{abstract}
This Cooperative Research and Development Agreement (CRADA) was undertaken to assess the applicability of the gelcasting process for forming automotive exhaust port liner green bodies using Golden Technologies' proprietary aluminum titanate powder composition. A gelcasting process, specifically tailored to Golden Technologies' powder, was developed and used successfully to form green bodies for property evaluation. Using appropriate milling and firing conditions, it was found that the gelcast material had properties which compared favorably with Golden Technologies' baseline material. Tubular gelcast samples simulating exhaust port liners were prepared and shipped to Golden Technologies for final process evaluation.
\end{abstract}

\title{
CRADA Objectives
}

The desired result of this CRADA was the successful demonstration of the gelcasting process for forming exhaust port liner green bodies using the Participant's aluminum titanate powder composition. Success was judged by the quality of the castings and by the measurement of the properties of the gelcast samples.

\section{Meeting Objectives}

The technical objectives of this CRADA were met in a timely manner with good interaction between ORNL and Golden Technologies.

\section{CRADA Benefit to DOE}

Conduct of research under this agreement served to increase our understanding of the important ceramic powder characteristics and processing parameters which govern successful application of the gelcasting ceramic forming method.

\section{Technical Discussion}

\section{Introduction}

The purpose of this Cooperative Research and Development Agreement (CRADA) was to assess the applicability of the gelcasting process for forming automotive exhaust port liner green bodies using Golden Technologies' proprietary aluminum titanate powder composition. The gelcasting process has been used successfully to form green bodies from numerous ceramic materials, including silicon nitride, silicon carbide, alumina, zirconia, etc. During these prior investigations, it was observed that the gelcasting process must be tailored to each specific material. This is primarily due to the fact that gelcasting is a chemical process and any variation in the chemistry of the system will affect the characteristics of the process.

Golden Technologies had a desire to evaluate the gelcasting process as a forming method for production of ceramic components for automotive applications. In order to gain confidence in the applicability of the process using their proprietary composition and to minimize the learning curve required for tailoring the process to this material, a cooperative research effort was proposed. ORNL provided the expertise and equipment for working with the gelcasting process, while Golden Technologies provided the ceramic powder, powder processing parameters, sintering process parameters, and testing expertise to evaluate the gelcast material. The desired result of the CRADA was the successful demonstration of the gelcasting process for forming exhaust port liner green bodies using Golden Technologies aluminum titanate powder composition. 


\section{Gelcasting Process Development}

Initial gelcasting trials using Golden's slip casting slurry formulation in the MAMAMBAM gelcasting system showed good gelling properties but poor drying characteristics. Additives in the slurry formula apparently sealed off the pore structure at the surface of the cast samples during the early stages of drying and strongly inhibited drying of the bulk material. To address this difficulty, the individual starting materials were shipped from Golden to prepare an alternate aluminum titanate composition for gelcasting which eliminated some of the organic additives which had been used in the original formulation. Using the altered formula, the slurries showed good viscosity and gelling characteristics, and dried at rates similar to other gelcast materials.

\section{Property Determination}

Samples in both plate and tubular form were cast and fired. The density of the samples fired at ORNL was somewhat less than that observed in firings of the baseline material at Golden. Particle size measurement of the milled slurry showed a particle size distribution which was coarser than the baseline slip casting material. Samples were sent to Golden for evaluation and comparison. Their tests showed results in agreement with the findings obtained at ORNL. It was believed that correction of the particle size distribution would improve the fired density. Approaches for improving the milling of the aluminum titanate powder composition were discussed and alternative milling procedures were evaluated.

Milling all of the constituent powders simultaneously at the desired solids loading did not result in adequate particle size refinement and narrowing of the particle size range. Analysis of the individual starting powders showed that two of the components, titania and silica, were very coarse and were skewing the particle size distribution in the batches. To improve the milling, these two powders were milled separately to refine the particle size before adding the remaining ceramic powders. This resulted in a significant change in the overall particle size distribution of the slurry.

Gelcast samples from these batches were dried and fired. The target density for the fired materials was $3.10 \mathrm{~g} / \mathrm{cm}^{3}$. Two firing profiles were evaluated. The first was the normal firing schedule used by Golden which had a $30 \mathrm{~min}$. hold at the peak temperature. The fired density under these conditions for the gelcast material was $2.85 \mathrm{~g} / \mathrm{cm}^{3}$. The second firing schedule had a faster heating rate and a hold of 4 hours at the peak temperature. Under these firing conditions, the density was $3.04 \mathrm{~g} / \mathrm{cm}^{3}$. Sintering trials conducted at Golden on gelcast samples prepared at ORNL confirmed the densification results which had been observed at Oak Ridge. The aluminum titanate material fired to a density of about $3.05 \mathrm{~g} / \mathrm{cm}^{3}$, comparable to the results typically obtained for the conventionally processed material.

\section{Part Fabrication}

Samples of thin-walled tubes were gelcast at ORNL for evaluation by Golden. The tubes had a 1.25 in. outer diameter with a wall thickness of about 0.08 in. and were 4 to 5 in. long. In firing trials at Golden, the tubes showed some distortion during the sintering process. It was decided that the thicker-walled tubes $(0.125$ to $0.25 \mathrm{in}$.) which had been prepared in earlier gelcasting trials would be used for the final evaluation of the gelcast materials for use as exhaust port liners. After discussion with the principal investigator at Golden, it was decided that the most desirable tube dimensions would be about 1.25 in. outer diameter, 0.125 in. wall thickness, and 6.0 in. long. An appropriate mold was prepared and the aluminum titanate tubes were gelcast. After drying, five tubes were 
shipped to Golden for final evaluation of the use of the gelcasting process for fabricating these components.

\section{Conclusions}

This Cooperative Research and Development Agreement (CRADA) was undertaken to assess the applicability of the gelcasting process for forming automotive exhaust port liner green bodies using Golden Technologies' proprietary aluminum titanate powder composition. A gelcasting process, specifically tailored to Golden Technologies' powder, was developed and used successfully to form green bodies for property evaluation. Using appropriate milling and firing conditions, it was found that the gelcast material had properties which compared favorably with Golden Technologies' baseline material. Tubular gelcast samples simulating exhaust port liners were prepared and shipped to Golden Technologies for final evaluation of the process.

\section{Report of Inventions}

There were no inventions developed under this agreement.

\section{Commercialization Possibilities}

The specific gelcasting process developed under this agreement may be commercialized at some time in the future, however, there are no such plans presently in place.

\section{Plans for Future Collaboration}

No plans have been made for future collaboration.

\section{Conclusions}

The technical objectives of this CRADA were met in a timely manner with good interaction between ORNL and Golden Technologies. Special attention needed to be directed to removing compositional additives which interferred with the gelcasting process and to modifying the milling procedure to obtain an overall particle size distribution which would yield the desired fired density. Both of these problems were overcome to produce a satisfactory gelcast material. 


\section{DISTRIBUTION}

1. Robert B. Schulz, Office of Heavy Vehicle Technologies, DOE, EE-33, 1000 Independence Avenue, S.W., Washington, D.C. 20585

2-3. Office of Scientific and Techical Information, P. O. Box 62, Oak Ridge, TN 37831

4. Work for Others Office, DOE-ORO, ER-113, P. O. Box 2001, Oak Ridge, TN 37831

5. P. L. Gorman, DOE-ORO, ORNL Site Office, P. O. Box 2008, Oak Ridge, TN 37831-6269

6. Dean Rulis, Golden Technologies Company, Inc., 4545 McIntyre Street, Golden, CO 80403

7. R. A. Bradley

8. D. F. Craig

9. R. G. Gilliland

10. D. R. Hamrin

11. D. R. Johnson

12. R. J. Lauf

13. A. J. Luffman

14. S. D. Nunn

15. A. C. Schaffhauser

16. C. A. Valentine 